\title{
A GAMING DIE IN THE HAND OF AN UNFORTUNATE CHILD
}

\author{
Vlasta Vyroubal \\ Croatian Academy of Sciences and Arts \\ Anthropological Centre \\ Ante Kovačića 5 \\ HR - 10000 Zagreb \\ vyroubal@hazu.hr
}

\author{
Petar Sekulić \\ Croatian Conservation Institute \\ Nike Grškovića 23 \\ HR - 10000 Zagreb \\ psekulic@hrz.hr
}

UDK / UDC: 903.2(497.541 Rudina)"14/15"

Izvorni znanstveni rad / Original scientific paper

https://doi.org/10.52064/vamz.54.1.25

The revision of the archaeological excavations of the Benedictine Abbey of St Michael the Archangel, in Rudina (2018), covered most of the rectangular area in front of the southern annexe of the abbey church. Thirty graves were found in the excavated area, most of which can be dated to the second half of the $15^{\text {th }}$ century

\section{Key words:}

Rudina, Benedictine Abbey, St Michael the Archangel, late Middle Ages, conservation and restoration work, gaming die, bio-anthropological analysis

\section{Benedictine Abbey, St Michael the Archangel}

The Benedictine Abbey of St Michael the Archangel, in Rudina, is located on the southeastern slopes of Psunj (Fig. 1). The abbey was first mentioned in a document of 1250, in the time of King Bela IV, but it is assumed that it was founded by members of the Boric family during the second half of the $12^{\text {th }}$ century. Due to the Ottoman threat, the abbey was abandoned during the second quarter of the $16^{\text {th }}$ century. ${ }^{1}$

In 2013, the Croatian Conservation Institute, in cooperation with the Požega Conservation Department, began a programme of archaeological excavations and the preparation of draft documentation for the remains of the Benedictine abbey in Rudina. This survey created the preconditions for conservation-restoration work with adequate presentation of this exceptional monument of late-medieval cultural heritage. and the beginning of the $16^{\text {th }}$. Remains of a subadult with head injuries indicative of interpersonal violence (who had a bone die in his right hand) were found in grave 43 . This grave dates back to the second half of the $15^{\text {th }}$ century and the beginning of the $16^{\text {th }}$.

As part of this work in 2018, an audit archaeological survey of the rectangular area in front of the southern annexe of the abbey church was conducted. It is an area (dimensions $10.9 \times 4.85 \mathrm{~m}$ ), which is delimited to the east by the west façade of the southern annexe next to the abbey church, and to the north by the southern part of its lobby. The wall bounding the subject area to its west and south, with some caution, can be interpreted as a remnant of an external defensive wall, probably built in the late $15^{\text {th }}$ century or early $16^{\text {th }}$. $^{2}$ In addition to the previously known four stone-lined tombs, another 30 graves were excavated in 2018 Most of the excavated graves may have existed before the construction of the external defensive wall. ${ }^{3}$
Sekulić 2020, 67

Based on the movable finds from the graves, it is possible to make such an ssumption (Mostarčić, Sekulić 2019, 126). 
FIGURE 1. Location of the site (made by P. Sekulić).

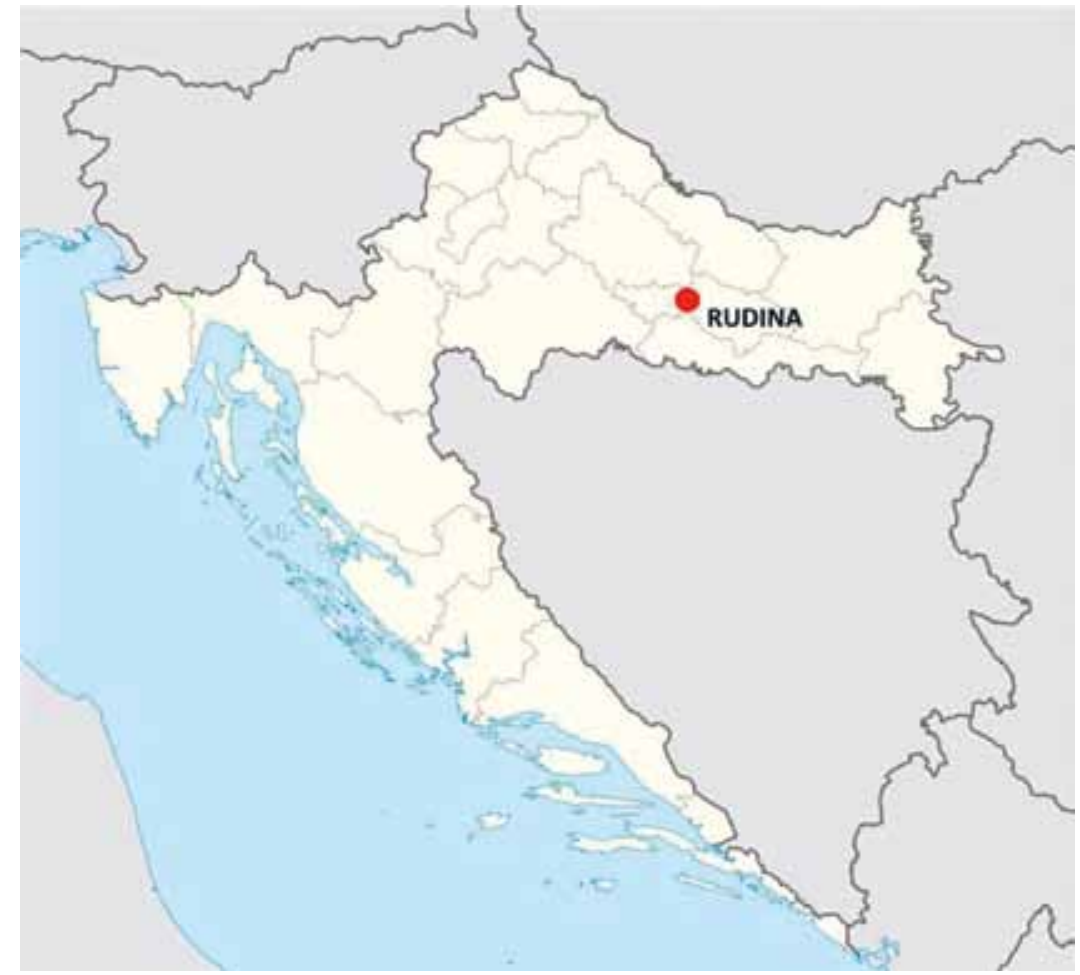

Grave 43 was documented in the south-eastern part of the area excavated in 2018 (Fig. 2). The grave was properly oriented (head to the west, feet to the east), partially preserved, arms stretched along the body and undisturbed by later burials (Fig. 3). A bone die (PN 027) was found in the right hand (Fig. 4), and a fragment of a poorly preserved iron hoop (PN 028) was found next to the right elbow.

\section{Osteography}

The osteological material from grave 43 of the archaeological site of Rudina-Benedictine Abbey of St Michael was in an excellent state of preservation, with almost the entire skeleton intact: only facial bones (the maxilla and both zygoma) and the left radius were missing. Evaluation of the cortex was done completely macroscopically, and since the outer layer of the bone was perfectly preserved, with no postmortem or taphonomic changes, the preservation of the cortex was assessed as excellent. The excellent preservation of the cortex made it possible to record any pathological conditions that might have left traces on dry bone. Age at death was estimated at between 9 and 11 years using Scheuer and Black (2004) criteria, ${ }^{4}$ primarily depending on dental calcification and chronology of formation and eruption of permanent dentition. Generally, the pelvis is the skeletal element that shows the highest degree of sexual dimorphism. ${ }^{5}$ According to Weaver $(1980)^{6}$ and Fazekas and Kósa (1978), 7 the differences between the male and female pelvis mirror the later sexual dimorphism of the pelvis found in adults. Boucher's (1957) ${ }^{8}$ investigation of the subadult ischial and pubis bones found major differences in the subpubic angle. The timing of fusion of the ischium and pubis is variable, but it normally occurs between 5 and 8 years. ${ }^{9}$ Since the morphology of the pubic ramus is one of the key elements in assessing an individual's sex, it is estimated that the remains from grave 43 belong to a young boy.

Pathologies observed on the subadult skeleton from grave 43 include changes to both the cranium and postcranium. Four antemortem blunt-force traumas (Fig. 5) are found on the cranium: 1) the right side of the frontal bone exhibits a lesion that is perfectly round in shape, measuring $22 \mathrm{~mm}$ in diameter (Fig. 6). Bulging of the bone is evident on the endocranial side; 2) blunt-force trauma on the left side of the frontal bone, oval in shape, measuring $7 \times 5 \mathrm{~mm}$; 3) blunt-force trauma located inferior to the previous one, also oval, measuring $3 \times 4 \mathrm{~mm}$; 4 ) blunt-force trauma on the occipital bone, oval in shape, measuring $5 \times 8 \mathrm{~mm}$.

A depressed skull fracture is a break in the cranial bone with depression of the bone inwards towards the brain. It is a type of fracture usually resulting from blunt-force trauma (such as getting struck with a hammer) and presents a high risk of increased 


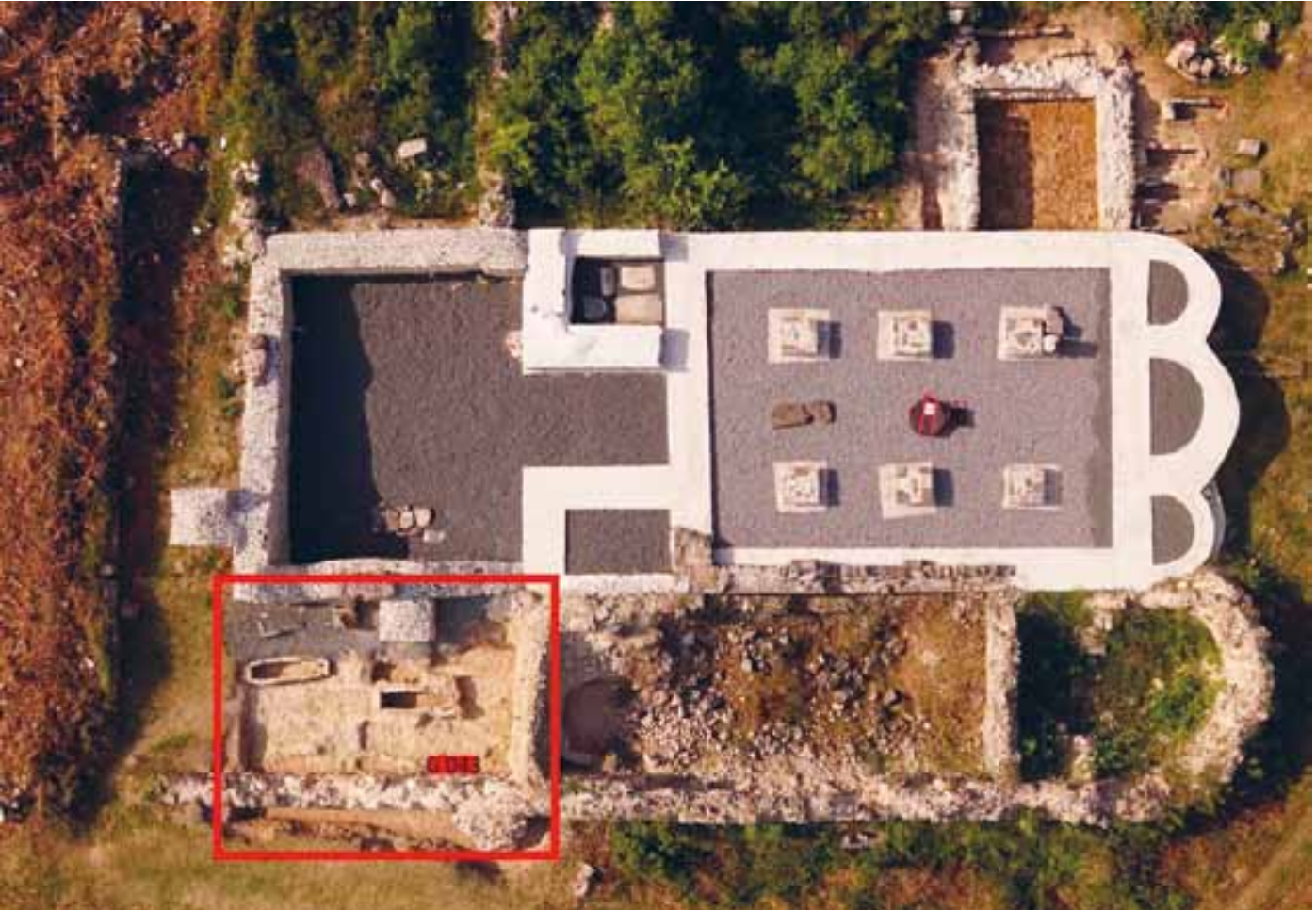

FIGURE 2. Aerial photo with the location of grave 43 (photo by Vektra d.o.o.)

pressure on the brain, or a haemorrhage of the brain that crushes the delicate tissue. A fracture in healthy bone indicates that a substantial amount of force has been applied and increases the possibility of associated injury. Any significant blow to the head results in a concussion, with or without loss of consciousness. Depressed skull fractures are associated with higher rates of in fection, seizure, neurological deficits, and death. ${ }^{10}$ Antemortem fractures in the archaeological context are relatively rare in subadult skeletons, and those found in the cranium even rarer. A holistic study of antemortem traumas has shown an incidence of $3.8 \%$ of subadult traumas in the postcranium and $2 \%$ in the cranium $^{11}$ recorded in the Croatian Late Medieval skeletal series.

From the bio-anthropological point of view, what stands out in the skeletal remains of this individual are the antemortem bluntforce traumas in the cranium, especially when the individual's age is taken into account. The distribution of these cranial lesions suggests a certain level of interpersonal violence.

The injury to the skull of the deceased corresponds to the shape and dimensions of the face of a war hammer (Cro. nadžak). A war hammer is a medieval weapon consisting of a beak, an eyelet and a face. Due to an increase in the degree of armour protection that reduced the effectiveness of infantry melee weapons, the war hammer developed from the war axe during the $14^{\text {th }}$ century.
On one side of the weapon, a beak-shaped extension was created to pierce the armour, while on the other end, a massive hammerlike face was developed that allowed for heavier blows (Fig. 7). Originally an infantry weapon, it became a standard piece of equestrian equipment.. ${ }^{12}$ The injury caused by the weapon was also small and rarely immediately fatal.

Dental caries is recorded in the mandibular deciduous molar. Linear enamel hypoplasia (LEH) is recorded in the permanent dentition. LEH is generally defined as any macroscopic defect in the enamel surface. ${ }^{13}$ These defects have been used as a nonspecific indicator of systemic physiological stress. ${ }^{14}$

Dental remains are one of the most enduring physical indicators of an individual's quality of life, and as such provide a very useful insight into the lifestyles of past populations, especially their dietary habits, but also the environmental conditions in which these populations lived. ${ }^{15}$ Dental caries is an infectious disease characterised by the demineralisation of inorganic portions and the destruction of organic portions of the teeth. The presence of caries was diagnosed macroscopically, under strong illumination, with the help of a dental probe. This disease is infectious and transferable, and by nature it is progressive, because the maintenance of the same conditions that cause carious lesions ultimately results in the destruction of the tooth. ${ }^{16} \mathrm{~A}$ higher fre-
10 Samandouras (ed.) 2010

11 Adamić Hadžić 2021.

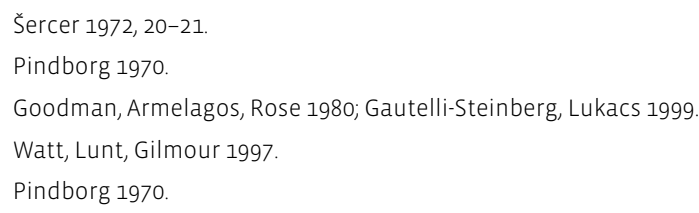




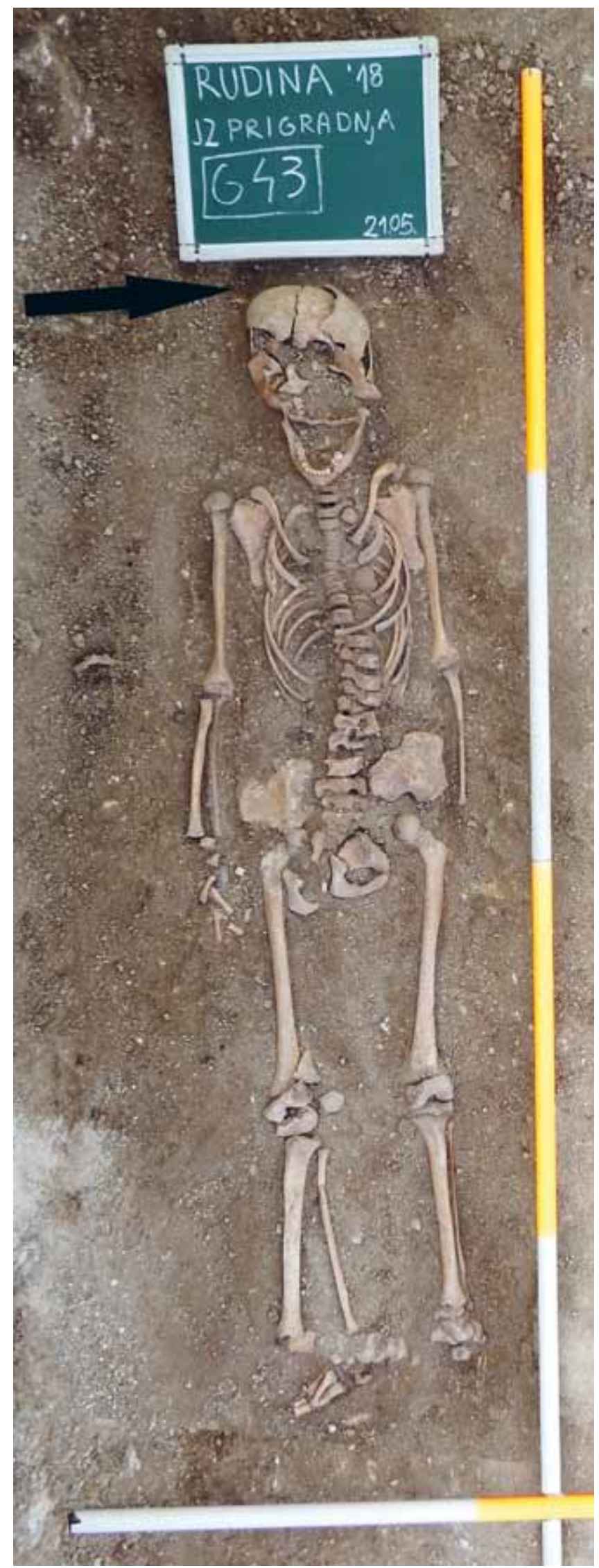

FIGURE 3. Grave 43 in situ (photo by P. Sekulić). quency of dental caries has been noted among populations dependent on agriculture. ${ }^{17}$ Populations dependent on agriculture have diets with a higher quantity of carbohydrates: the starch and sugar found in wheat, maize and other crops cultivated at the archaeological sites contained $45 \%$ to $80 \%$ of the total calories in the diets of pre-industrial agricultural populations..$^{18}$

Written historical sources such as urbarii (medieval legal documents which defined relationships between feudal lords and peasants) provide information on the lifestyle of medieval Croatian populations. These urbarii very well exhibit which types of food were used by the different social categories during this period. Millet was the main crop that made up the basis of the everyday diet, because it is easily cultivated, has a short period of vegetation, and can be sown in dry and sandy soil. Wheat was considered the most important cereal for baking bread, while buckwheat and guinea corn also played a very important role in the everyday diet. Besides these crops, rye and barley were also cultivated in large amounts. On the other hand, pork, poultry and fish were the most common sources of protein for Croatian peasants during the Late Middle Ages. ${ }^{19}$

Pathologies recorded in the postcranium are active inflammatory processes (periostitis) on both calcanei. Non-specific periostitis is a basic inflammatory response that develops because of non-specific bacterial infection ${ }^{20}$, and also from trauma and from specific infectious diseases such as leprosy, tuberculosis, treponemal disease, and even from conditions such as fluorosis. ${ }^{21}$

Furthermore, both humeri exhibit pronounced entheses of the deltoid muscle (Fig. 8). Pronounced entheses and benign cortical defects are usually associated with excessive muscle use. ${ }^{22}$ The deltoid muscle is the muscle forming the rounded contour of the human shoulder. It is the prime mover of arm abduction. It also enables the precise and rapid movement needed for hand and arm manipulation. ${ }^{23}$ The deltoid is responsible for elevating the arm. Pronounced muscle attachment sites on the bone suggest an extensive use of the muscle. Excessive use of the muscles of the upper part of the body (arms) can be attributed to repetitive motions like lifting and swaying back and forth. ${ }^{24}$

\footnotetext{
17 Armelagos 1969; Tóth 1970; Wells 1975; Larsen, Shavit, Griffin 1991; O'Sullivan et al. 1993; Fujita 1995.

18 Guthrie 1979.

19 Adamček 1980

20 Ortner 2003.

21 Larsen 1997; Ortner 2003.

22 Resnick, Greenway 1982.

23 Potau et al. 2009
} 


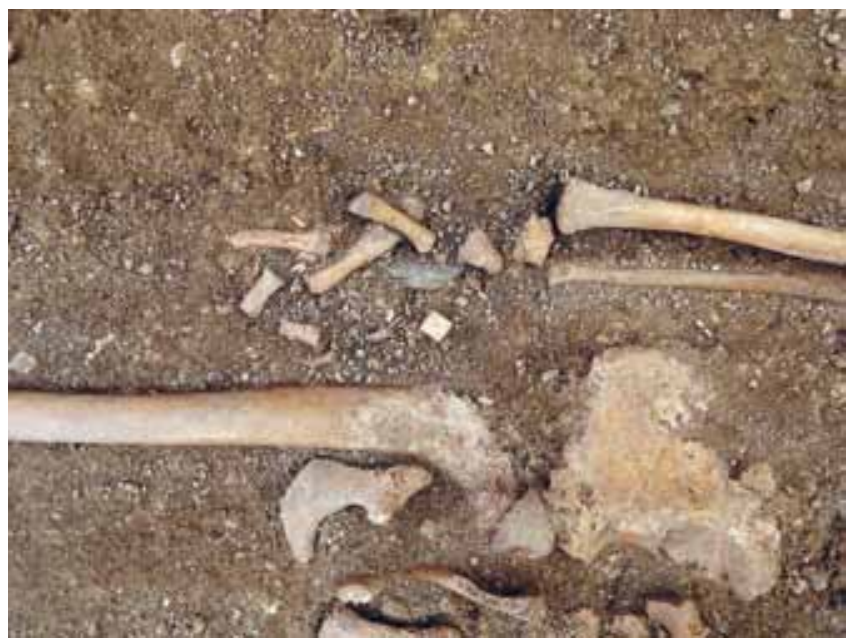

FIGURE 4. Bone die in situ (photo by P. Sekulić).

\section{The bone die}

The bone die found in the right hand of the deceased from grave 43, excavated in 2018, is particularly interesting (Fig. 9). It is a hexagonal bone ${ }^{25}$ die measuring $1.1 \times 1.0 \times 1.1 \mathrm{~cm}$, the diameter of its dots being $1.5 \mathrm{~mm}$, and its weight 2 grams. Typologically, it can be classified as the so-called type of tesser, in which the dots represent a value of one to six, and the sum of the opposite sides is always seven (Fig. 10). On the basis of its characteristics, it is possible to assume that this is a type of die that usually dates to the period after $1450 .{ }^{26}$

It is assumed that the earliest dice originated in Asia during the third millennium $\mathrm{BC}$, while in the area of present-day Croatia they appeared during Roman rule. ${ }^{27}$

The importance of dice games, including games of chance, in the development of culture and civilization, was pointed out by the Dutch historian Johan Huizing in his Homo ludens in 1938. According to Huizing, the influence of games on freedom of thought, ingenuity and creativity through leisure has influenced the general progress of civilization. ${ }^{28}$ In addition to these effects, it should be emphasized that the concept of happiness was an
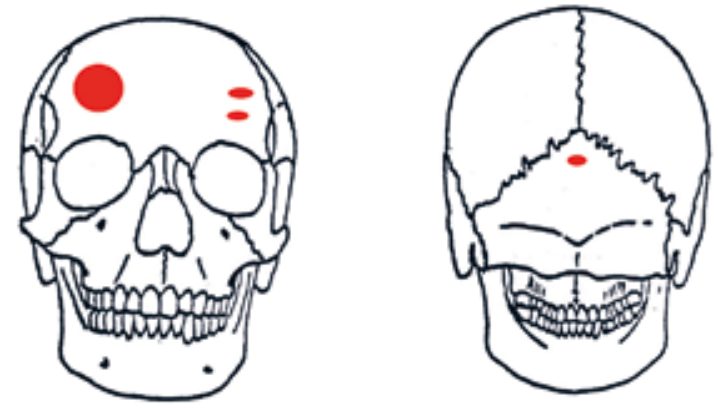

FIGURE 5. Distribution of the cranial traumas (made by V. Vyroubal).

important life factor in everyday medieval life, so dice must be viewed in the context of medieval superstition.

Numerous written sources and depictions testify to a large number of games ${ }^{29}$ and their wide distribution in all segments of society: from secular and ecclesiastical rulers through the nobility, clergy and monks ${ }^{30}$ to the common people. ${ }^{31}$ Since festivities and celebrations were part of everyday medieval life (from several days of Christmas celebrations through Lent carnivals to celebrations of patron saints and family celebrations), so the various games were an integral part of them. ${ }^{32}$ In addition to games of skill and practice, there were games of chance and socalled mixed games that combined both. Unlike other pastimes, gambling was regulated by legal provisions, and was the subject of moral debate and sometimes condemnation. ${ }^{33}$ In games of chance, the player does not prove his mental and physical skills; rather, the course of the game is marked by unpredictability. ${ }^{34}$

The most widespread games of medieval Europe which included dice were backgammon (Lat. tabulas, Ger. wurfzabel, Fr. tric-trac, Ita. tavole reale) and mill. ${ }^{35}$ They, like chess, spread across Europe

\footnotetext{
24 Killgrove 2010

25 Due to their strength, shape and availability, the metacarpal bones of cat tle were most commonly used. They were shaped into square bars from which cubes were obtained/cut (Erath 1996, 72)

26 Eerkens, Voogt 2017, 172

27 Kovač 2017, 208-211.

28 Meier 2010, 77
}

29 The statutes of Italian cities mention over 200 different games (Fabijanec 2009, 21-22)

30 Different items of the gaming inventory have been found during archaeological excavations of numerous medieval monasteries across Europe (Meier 2010, 79; Hall 2015, 283-291). The scale is evidenced, among other things, by the provision of the Synod held in Würzburg in 1329, which forbade monks from playing (ludus alearum, cartarum, taxillorum, anulorum et globo-rum monachis et monialibus prohibemus destricte) (Meier 2010, 90)

\footnotetext{
31 Meier 2010, 80-83.

32 Fabijanec 2009, 21

33 Fabijanec 2009, 23

34 Fabijanec 2009, 24

35 Schädler 2000, 112-115; Meier 2010, 77
} 


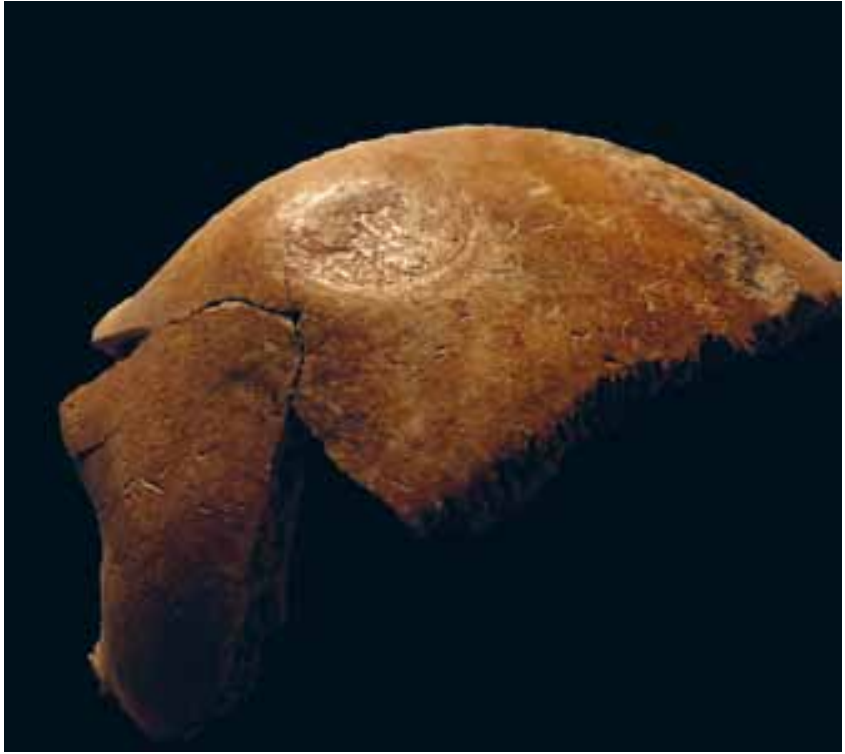

FIGURE 6. Antemortem blunt-force trauma on the right side of the frontal bone (photo by V. Vyroubal).

after the Crusades. In addition to games that included a game board, several different games of chance required only a die (alea, taxillos)..$^{36}$ In the $14^{\text {th }}$ and $15^{\text {th }}$ centuries, dice games gradually lost popularity due to the spread of card games. ${ }^{37}$ The negative social aspects of games and gambling resulted in numerous attempts at restraint and control by secular and ecclesiastical rulers and city authorities. ${ }^{38}$ From the second half of the $14^{\text {th }}$ century, restrictions on the regulation of games of chance (such as determining the permitted game, time and place, organization of city casinos, etc.) also became more frequent in city statutes. ${ }^{39}$

In addition to gambling, dice were also used to make political and legal decisions such as voting, candidate selection, recruitment, resolving disputes, dividing property, and enforcing criminal provisions. ${ }^{40}$

The attitude of the Church towards games encompassed a concern for the bad habits of medieval society, but it is not possible to speak of the existence of a unified attitude. ${ }^{41}$ Given the importance and prevalence of games in medieval society, the Church's strategy in the Late Middle Ages consisted of balancing public approval and attempts at metaphorical inclusion in the cult of saints on the one hand, and condemnation on the other. ${ }^{42}$ The reason there was a certain level of acceptance of games of chance is a reflection of the economic and socio-historical de-

36 On the names and classification of games mentioned in the statutes of medieval towns on the eastern Adriatic coast, see Fabijanec (2009, 24-27).

37 Eerkens, Voogt 2017, 163

38 Fabijanec 2009, 37-39; Meier 2010, 89-93; Schädler 2012, 23-47.

39 Fabijanec 2009, 35-39; Meier 2010, 93-91.

40 Erath 1996, 96; Meier 2010, 83; Binde 2014, 4-5

41 Fabijanec 2009, 48-49.

42 Fabijanec 2009, 40-48; Hall 2015, 294.

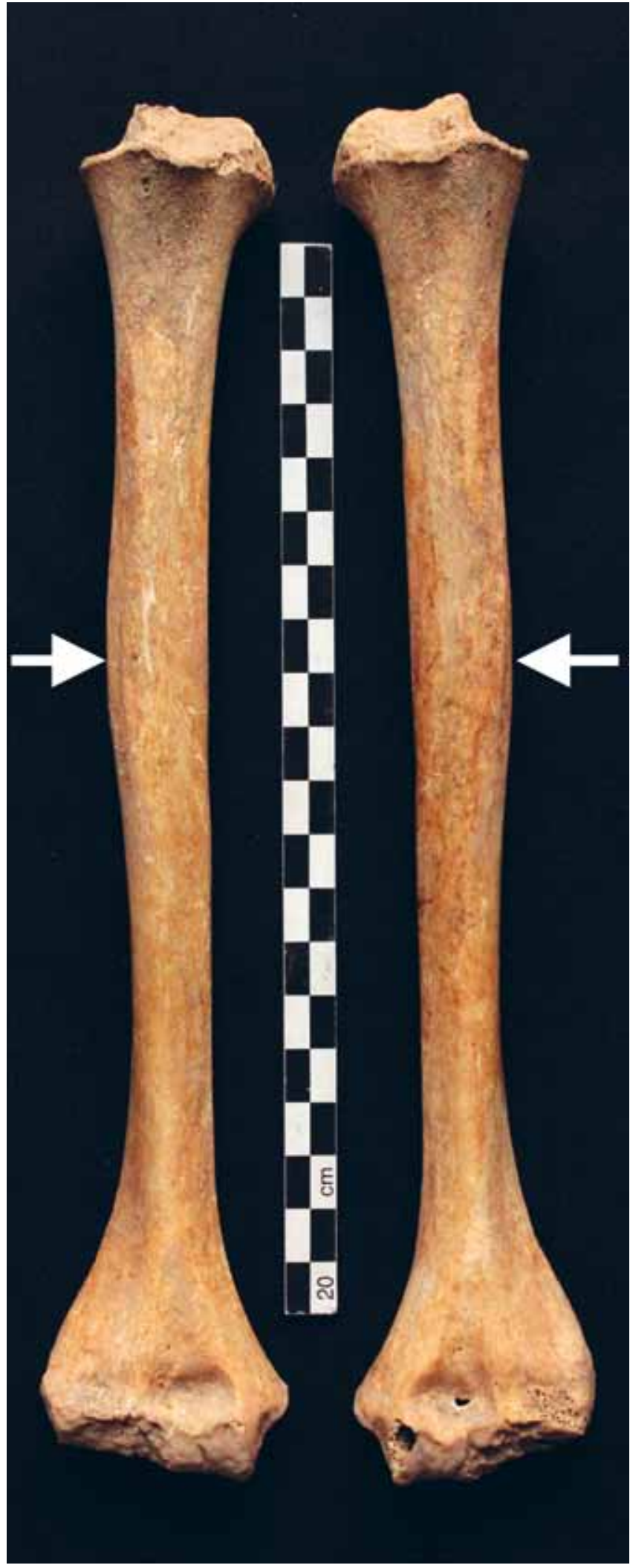

FIGURE 7. Pronounced attachments for the deltoid muscle (photo by $\mathrm{V}$. Vyroubal). 


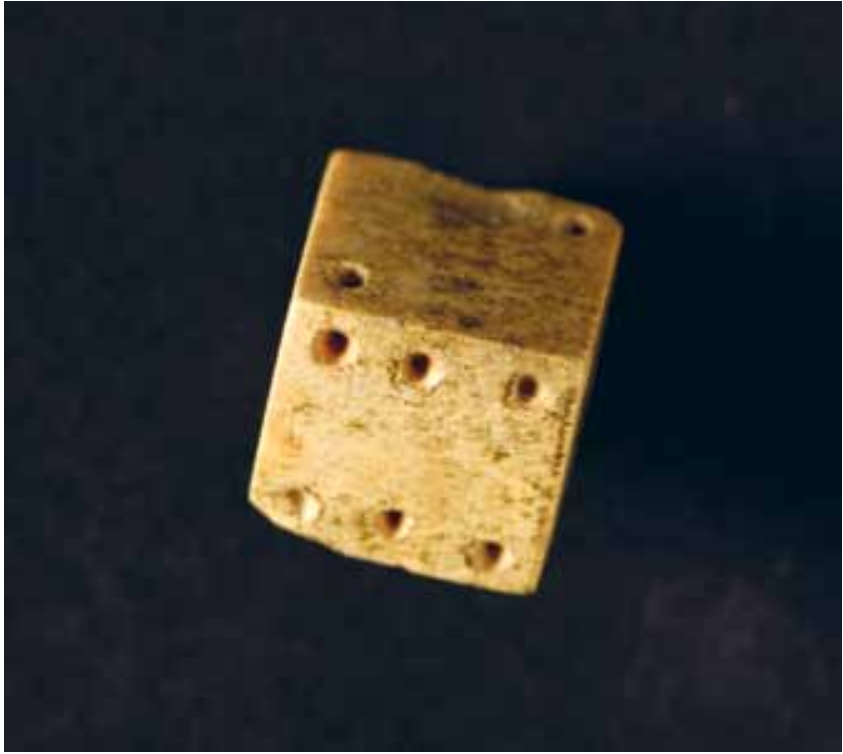

FIGURE 8. Bone die from grave 43 (photo by P. Sekulić).

velopment during the period of the High Middle Ages. A large number of Church intellectuals pursued a more tolerant attitude towards human sinfulness and the possibility of redemption..$^{43} \mathrm{It}$ was not until the $16^{\text {th }}$ century that attitudes towards gambling intensified due to the Catholic Reformation's efforts to regain its shaky position. ${ }^{44}$

Preserved medieval written sources testify to the popularity of games among children ${ }^{45}$ and the government's attempts to protect them from negative effects..$^{46}$ Therefore, the observed finding can be interpreted as a kind of personal/sentimental contribution, which may indicate the personal affinity of the deceased for games. It cannot be ruled out that this is some kind of indication of superstition, or a form of popular piety unknown to us.

\section{Concluding remarks}

From the bio-anthropological point of view, what stands out in the skeletal remains of this individual are the antemortem bluntforce traumas in the cranium, especially when the individual's age is taken into account. The distribution of these cranial lesions suggests a certain level of interpersonal violence.

The injury to the skull of the deceased corresponds to the shape and dimensions of the face of a war hammer (nadžak). The use of war hammers is most often associated with the Ottoman light

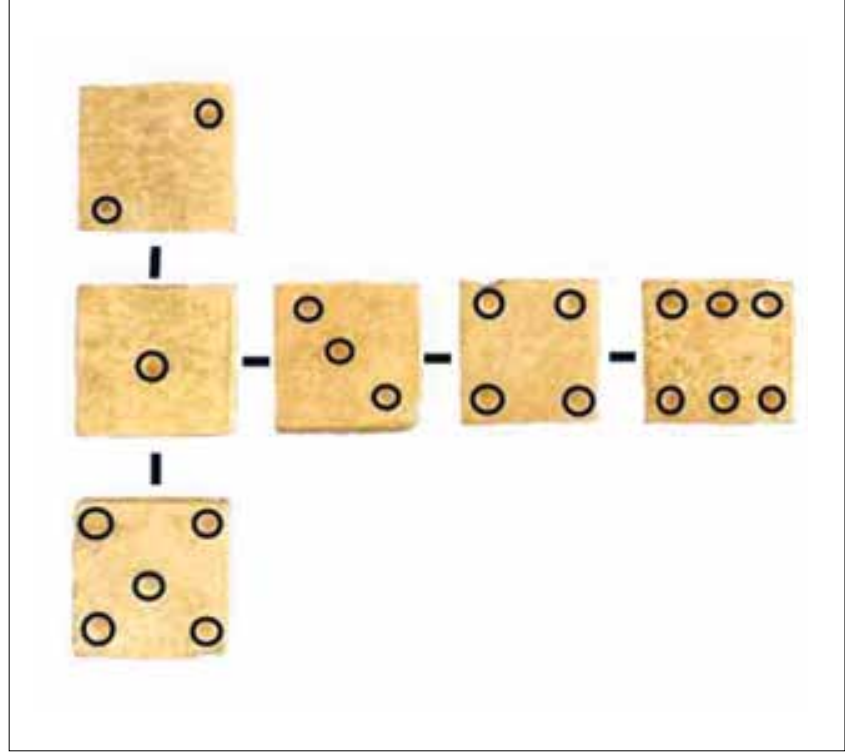

FIGURE 9. Bone die, schematic (made by P. Sekulić).

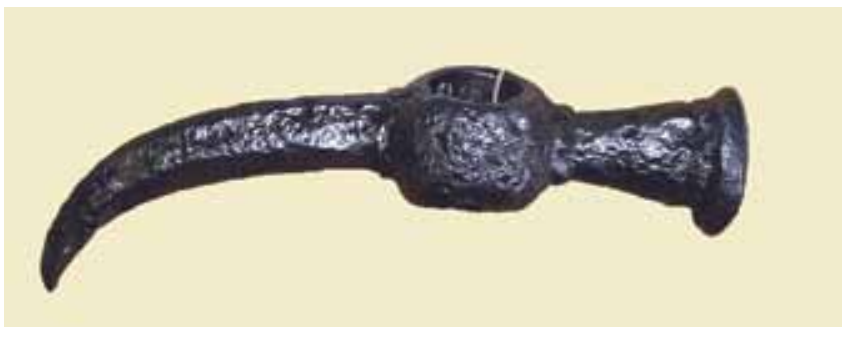

FIGURE 10. War hammer (photo by V. Vyroubal).

cavalry, whose attacks on the Požega valley were recorded several times during the $15^{\text {th }}$ century. ${ }^{47}$ Furthermore, from the appeal sent to Pope Nicholas V, it is evident that the abbey in Rudina was destroyed during the Ottoman raid on the Požega region in 1450. This petition, submitted to Pope Nicholas V on October 1, 1450, asked that forgiveness be granted to all who devoutly visited the monastery, i.e. the abbey church, and assist in the repair and renovation of the monastery, i.e. abbey buildings. ${ }^{48}$ Whether the said grave can be linked to any of the Ottoman attacks remains, for now, a matter of speculation. Since the blunt-force traumas recorded in the skeleton were well healed, there is a possibility that the child survived the violence and died some years later of an unrelated cause. Also, we can only speculate about the personal symbolic meaning of the bone die found in the hand of the child buried in grave 43 .

\footnotetext{
43 Fabijanec 2009, 48-49.

44 Fabijanec 2009, 49

45 On age and legal classification in medieval statutes, see Karbić $(2003,61-$ 62) and Ladić, Budeč (2020, 221).

46 Thus, the provisions of the Augsburg City Statute of 1276 prescribed the obligation to pay winnings to children, while the medieval Saxon Ordinary Code (Sächsischen Weichbild) stipulated that, in the case of impossibility to collect the debt from a child, the debt could be collected only by confiscating robes (Meier 2010, 81, 98).
}

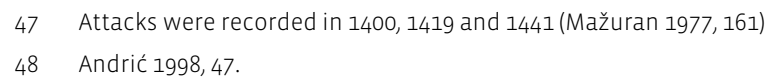

48 Andrić 1998, 47. 


\section{BIBLIOGRAPHY}

Adamček 1980 - J. Adamček, Agrarni odnosi u Hrvatskoj od sredine XV do kraja XVII stoljeća, Građa za gospodarsku povijet Hrvatske 18, Sveučilišna naklada Liber, 1980 .

Adamić Hadžić 2021 - A. Adamić Hadžić, Komparativna analiza trauma na ljudskom koštanom materijalu s područja Hrvatske od ranog srednjeg vijeka do ranog novog vijeka, unpublished PhD thesis, Sveučilište u Zadru, 2021.

Andrić 1998 - S. Andrić, Benediktinski samostan sv. Mihovila Arkanđela na Rudini, Zlatna dolina: godišnjak Požeštine 4, 1998, 31-57.

Andrić 2020 - S. Andrić, Rudina - benediktinski samostan sv. Mihaela Arkanđela, Monasticon Slavonicum, Sirmiense et Baraniense 1, Hrvatski institut za povijest - Podružnica za povijest Slavonije, Srijema i Baranje, 2020.

Armelagos 1969 - G. J. Armeloagos, Disease in ancient Nubia, Science 163, 1969, 255-259.

Binde 2014 - P. Binde, Games of life and death: The judicial uses of dice in eight eenth and nineteenth-century Sweden, UNLV Gaming Research \& Review Journal $18 / 1,2014,1-24$

Boucher 1957 - B. J. Boucher, Sex differences in the foetal pelvis, American Journal of Physical Anthropology 15, 1957, 581-600.

Caffey 1993 - J. Caffey, Pediatric X-ray diagnosis: a textbook for students and practitioners of pediatrics, surgery \& radiology, Year Book Publishers, 1993.

Eerkens, Voogt 2017 - J. W. Eerkens, A. de Voogt, The Evolution of Cubic Dice from the Roman through Post-Medieval Period in Netherlands, Acta archaeologica 88, Brill, 2017, 163-173

Erath 1996 - M. Erath, Studien zum mitelalterlichen Knochenschnitzerhandwerk: die Entwicklung eines spezialiserten Handwerks in Konstanz, Inaugural-Dissertation zur Erlangung der Doktorwürde der Philosophischen Fakultäten der Albert-Ludwigs-Universität zu Freiburg im Breisgau, 1996.

Fabijanec 2009 - S. F. Fabijanec, Ludus zardorum: moralni i zakonski okviri kockanja na Jadranu u srednjem vijeku, in Miljan, S. (ed.), Na rubu zakona: društveno $i$ pravno neprihvatljiva ponašanja kroz povijest, Zbornik radova sa znanstvenog kolokvija Dies Historiae održanog 13. prosinca 2007. u Zagrebu, Biblioteka Dies historiae 3, Hrvatski studij Sveučilišta u Zagrebu, 2009, 21-50.

Fazekas, Kósa 1978 - I. G. Fazekas, F. Kósa, Forensic Fetal Osteology, Akadémiai Kiadó, 1978.

Fujita $1995-\mathrm{H}$. Fujita, Geographical and chronological differences in dental caries in the Neolithic Jomon Period of Japan, Anthropological Science 103, 1995, 23-37.

Goodman, Armelagos, Rose 1980 - A. H. Goodman, G. J. Armelagos, J. C. Rose, Enamel hypoplasias as indicators of stress in three prehistoric populations from Illinois, Human Biology 52, 1980, 515-528.

Guatelli-Steinberg, Lukacs 1999 - D. Guatelli-Steinberg, J. R. Lukacs, Interpreting sex differences in enamel hypoplasia in human and non-human primates: Developmental, environmental and cultural considerations, Yearbook of Physical Anthropology 42, 1999, 73-126.

Guthrie 1979 - H. A. Guthrie, Introductory nutrition, C. V. Mosby, 1979

Hall 2015 - M. A. Hall, Ecclesia Ludens: board and dice games in a Scottish monastic context, Proceedings of the Society of Antiquaries of Scotland 145, 2015, 283-297.

Karbić 2003 - M. Karbić, Prilog poznavanju položaja djece u srednjovjekovnim gradskim naseljima u međurječju Save i Drave, Scrinia Slavonica : Godišnjak Podružnice za povijest Slavonije, Srijema i Baranje Hrvatskog instituta za povijest 3/1, 2003, 57-69.

Killgrove 2010 - K. Killgrove, Identifying immigrants to Imperial Rome using strontium isotope analysis, in Eckardt, $\mathrm{H}$. (ed.), Roman diasporas: archaeological approaches to mobility and diversity in the Roman Empire, Journal of Roman Archaeology, Supplement 78, 2010, 157-174

Kovač 2017 - M. Kovač, Tipologija i tehnologija izrade rimskih koštanih predmeta na području Donje Panonije na primjeru nalaza iz Murse, unpublished PhD thesis, Filozofski fakultet Sveučilišta u Zagrebu, 2017.

Ladić, Budeč 2020 - Z. Ladić, G. Budeč, Neki aspekti privatnog i obiteljskog života te razine materijalne kulture stanovništva Hrvatske u kasnom srednjem vijeku, in Karbić, M. (ed.), Vrijeme sazrijevanja, vrijeme razaranja. Hrvatske zemlje u kasnome srednjem vijeku, Biblioteka Povijest Hrvata 3, Matica hrvatska, 2020, 213-231.

Larsen 1997 - C. S. Larsen, Bioarchaeology. Interpreting behavior from the human skeleton, Cambridge studies in biological and evolutionary anthropology 21, Cambridge University Press, 1997.

Larsen, Shavit, Griffin 1991 - C. S. Larsen, R. Shavit, M. C. Griffin, Dental caries evidence for dietary change: an archaeological context, in Kelley, M. A., Larsen, C. S. (eds), Advances in Dental Anthropology, Wiley-Liss, 1991, 179-202.

Mažuran 1977 - I. Mažuran, Požega i Požeška kotlina za turske vladavine, in Strbašić, M. (ed.), Požega 1227-1977, Skupština općine Slavonska Požega - Odbor za proslavu 750. godišnjice grada Slavonske Požege, 1977, 161-198.

Meier 2010 - F. Meier, Der Teufel schuf das Würfelspiel... Brett- und Glücksspiele im Mittelalter, in Finkele, S., Krause, B. (eds.), Glück - Zufall - Vorsehung, Vortragsreihe der Abteilung Mediävistikdes Instituts für Literaturwissenschaft im Sommersemester 2008, KIT Scientific Publishing, 2010, 77-102.

Mostarčić, Sekulić 2019 - B. Mostarčić, P. Sekulić, Čečavac (Rudina), benediktinska opatija sv. Mihaela Arkanđela - izvještaj o arheološkim istraživanjima i građevinskim radovima konzerviranja i rekonstrukcije provedenim tijekom 2018. godine, unpublished report, Hrvatski restauratorski zavod, 2019.

Ortner 2003 - D. Ortner, Identification of Pathological Conditions in Human Skeletal Remains, Academic Press, 2003

O'Sullivan et al. 1993 - E.A. O'Sullivan, S. A .Williams, R. C. Wakefield, J. E. Cape, M. E. J. Curzon, Prevalence and site characteristics of dental caries in primary molar teeth from prehistoric times to the $18^{\text {th }}$ century in England, Caries Research 27/2, 1993,147-153.

Pindborg 1970 - J. J. Pindborg, Pathology of the dental hard tissues, Saunders, 1970

Pleše, Mostarčić, Sekulić 2018 - T. Pleše, B. Mostarčić, P. Sekulić, Ususret četvrtom desetljeću od početka istraživanja benediktinske opatije sv. Mihovila arkanđela na Rudini, Radovi Zavoda za znanstveni i umjetnički rad u Požegi 7, 2018, 91-135.

Potau et al. 2009 - J. M. Potau, X. Bardina, N. Ciurana, D. Camprubí, J. F. Pastor, F. de Paz, M. Barbosa, Quantitative Analysis of the Deltoid and Rotator Cuff Muscles in Humans and Great Apes, International Journal of Primatology 30/5, 2009, 697-708.

Resnick, Greenway 1982 - D. Resnick, G. Greenway, Distal femoral cortical defects, irregularities and excavations, Radiology 143/2, 1982, 345-354.

Samandouras (ed.) 2010 - G. Samandouras (ed.), The Neurosurgeons's Handbook, Oxford University Press, 2010

Schädler 2000 - U. Schädler, Medieval Nine-Men's Morris with Dice, Board Games Studies 3, 2000, 112-116.

Schädler 2012 - U. Schädler, Organizing the Greed for Gain: Alfonso X of Spain's Law on Gambling Houses, in Bornet, P., Burger, M. (eds.), Religions in Play. Games, Rituals, and Virtual Worlds, Culturel 2, Pano Verlag, 2012, 23-47.

Scheuer, Black 2004 - L. Scheuer, S. Black, Developmental Juvenile Osteology, Academic Press, 2004.

Sekulić 2020 - P. Sekulić, Čečavac (Rudina), benediktinska opatija sv. Mihaela Arkanđela - preliminarni izvještaj o arheološkim istraživanjima 2019, unpublished report, Arhiv Hrvatskog restauratorskog zavoda, 2020

Šercer 1972 - M. Šercer, Staro oružje na motki, Katalog muzejskih zbirki 7, Povijesni muzej Hrvatske, 1972.

Tóth 1970 - K. Tóth, The epidemiology of dental caries in Hungary, Akadémiai Kiadó, 1970.

Watt, Lunt, Gilmour 1997 - M. E. Watt, D. A. Lunt, W. H. Gilmour, Caries prevalence in the permanent dentition of a mediaeval population from the south-west of Scotland, Archives of Oral Biology 42/9, 601-620, 1997

Weaver 1980 - D. S. Weaver, Sex differences in the ilia of a known sex and age sample of fetal and infant skeletons, American Journal of Physical Anthropology $52 / 2,1980,191-195$

Wells 1975 - C. Wells, Prehistoric and historical changes in nutritional diseases and associated conditions, Progress in Food and Nutrition Science 1, 1975, 729779 . 